\title{
Risk assessment of finishing beef cattle in feedlot: slaughter weights and correlation amongst input variables
}

\author{
Paulo Santana Pacheco', Leonir Luiz Pascoal ${ }^{1}$, João Restle ${ }^{1}$, Fabiano Nunes Vaz ${ }^{1}$, \\ Miguelangelo Ziegler Arboitte ${ }^{1}$, Ricardo Zambarda Vaz ${ }^{1}$, João Paulo Aquino Santos ${ }^{1}$, \\ Thamyres Martino Liñares de Oliveira ${ }^{1}$
}

\begin{abstract}
${ }^{1}$ Departamento de Zootecnia, Universidade Federal de Santa Maria, Santa Maria, RS, Brasil.
ABSTRACT - The objective of this study was to evaluate the risk associated with finishing crossbred Charolais $\times$ Nellore steers in feedlot at different slaughter weights $(425,467$ or $510 \mathrm{~kg})$, considering or disregarding the correlation amongst random input variables. Data were collected from 2004 to 2010 and used in the simulation of the financial indicator Net Present Value (NPV). Animals slaughtered with 425, 467 or $510 \mathrm{~kg}$ were fed diets containing a roughage:concentrate ratio of 60:40 for 30, 65 and 94 days, respectively. In the simulation of NPV, a Latin Hypercube type of sampling was used, running 2000 interactions. An analysis of stochastic dominance of first and second orders was carried out as well as the KolmogorovSmirnov asymptotic test (to check for differences between pairs of curves of cumulative distributions), followed by sensitivity analysis using stepwise multivariate regression. Simulations of NPV considering the correlation amongst the input variables produced more consistent estimates of this financial indicator than simulations that disregarded it. The risk analysis showed that $467 \mathrm{~kg}$ slaughter weight presented the lowest risk for finishing cattle in feedlots when compared with 425 and $510 \mathrm{~kg}$. The most important variables influencing the NVP are the prices of feeder and finished steers, initial and final weights, concentrate and roughage costs, and minimum rate of attractiveness; therefore, farmers should pay particular attention to these variables when making the decision of whether or not to use feedlot to finish beef cattle.
\end{abstract}

Key Words: investment analysis, investment project, non-parametric statistics, production of young steers, probabilistic analysis, Monte Carlo simulation

\section{Introduction}

Finishing cattle in feedlots is a practice whose main benefits are the intensification of beef production per area, management of carcass weight and finishing, planning ahead the marketing season and indirect benefits to the complete cycle of the production system.

When compared with finishing on pastures, feedlot is very little expressive in Brazil (seven to eight percent of total slaughter - Anualpec, 2011), although technically well mastered, both from the nutritional as well as the management point of view. As for feedlot animals, there is a predominance of non-castrated and castrated Nellore zebu males and crossbreeds fed between 74 and 83 days and slaughtered between 489 and $501 \mathrm{~kg}$ (Millen et al., 2009). However, slaughter weights starting from $430 \mathrm{~kg}$ are common and accepted by the industry, provided they have proper carcass fattening (above three $\mathrm{mm}$ of subcutaneous fat thickness).

Thus, aspects of the economic viability can vary widely, because larger weights result in longer feeding time, and consequently an increase in operating expenses. This factor is relevant because in confinement variable costs are very significant, usually representing over $85 \%$ of the total cost (Pacheco et al., 2006; Lopes et al., 2011). This justifies further refinement in estimating the risks associated with items of cost/revenue as well as quantifying them as to the degree of importance in the output variable.

Quantifying the risk means determining all the possible values a variable can assume and the relative possibilities of each value (Palisade, 2010), in which decision making is made easier with the use of simulation techniques using software added on electronic spreadsheets, the Monte Carlo simulation being one of the most common (Mun, 2006). Economic feasibility studies of beef cattle feedlot (Resende Filho et al., 2001; Simões et al., 2007) have used Monte Carlo simulation, but did not evaluate the impact on the output variable with or without use of correlations between input variables. This consideration was the reason for research in other areas (Wall, 1997; Yang, 2005) where the use of correlation resulted in significant changes in the simulated output variable, being more important than the choice of the type of distribution of random variables.

Therefore, the aim of this study was to evaluate the risk of feedlot-finishing steers slaughtered at different weights, 
using or disregarding a correlation between the input variables, by simulating the Net Present Value financial indicator.

\section{Material and Methods}

Information of animal performance and experimental diet (roughage and concentrate) was used in the calculations of production costs as well as in the simulation of financial indicator. This experiment was conducted in the Department of Animal Science, Universidade Federal de Santa Maria, Rio Grande do Sul - Brazil $\left(29^{\circ} 43^{\prime}\right.$ South latitude and $53^{\circ} 42^{\prime}$ West longitude).

In the period prior to the beginning of the feedlot finishing phase, the animals were raised on native pasture in the summer, consisting primarily of Eragrostis plana Nees, Paspalum notatum, Axonopus affinis and Desmodium incanum. During the winter, the animals were kept on pasture intercropping of Avena strigosa Schreb and Lolium multiflorum Lam.

Eighteen castrated 5/8Nellore $\times 3 / 8$ Charolais contemporary animals from the same experimental herd with initial average age and weight of 660 days and $361 \pm 38.6 \mathrm{~kg}$, respectively, were used.

The diet was calculated according to NRC (1996), containing $10.25 \%$ crude protein and $3.18 \mathrm{Mcal}$ of digestible energy $/ \mathrm{kg}$ dry matter (DM). The roughage:concentrate ratio was 60:40, and the percentage of participation of DM in the diet was: $60 \%$ corn silage, $28.24 \%$ wheat bran, $10.07 \%$ sorghum grain, $0.17 \%$ urea (45-00-00), $1.02 \%$ limestone, $0.48 \% \mathrm{NaCl}$ and $0.0128 \%$ ionophore (Rumensin ${ }^{\circledR}$ ).

The intended slaughter weights were 420,460 and $500 \mathrm{~kg}$, and the actual slaughter weights were 425,467 and $510 \mathrm{~kg}$, respectively. The feedlot feeding periods were 30,65 and 94 days, respectively. In all treatments, the beginning of confinement occurred in August and the sale occurred as the animals reached their slaughter weights. The animals presented carcasses with average subcutaneous fat thickness of 3.6, 6.3, and $7.3 \pm 0.51 \mathrm{~mm}$, respectively. All the values were within the minimum required by the meatpacking industry (three $\mathrm{mm}$ ), enabling the commercialization of cattle with any slaughter weight studied.

The correlation amongst the input variables was also evaluated in the simulation of the financial indicator to check for robustness results. Calculation methodologies proposed by Matsunaga et al. (1976) and Resende Filho et al. (2001) were used considering the average prices (in $\mathrm{R} \$$ ) practiced in the state of Rio Grande do Sul from 2004 to 2010 (Conab, 2010; Anualpec, 2011). All costs were estimated per animal.
The total cost corresponded to the sum of depreciation (facilities, machinery, implements and equipment), the feeder steer purchase price, sanitary control, feed (roughage and concentrate), labor and other operating expenses. Gross revenues consisted of the sale of the finished animal.

The facilities costs were estimated for static capacity of 1,000 animals. Depreciation of infra-structure, machinery, implements and equipment were calculated for a planning horizon of one year.

To calculate the production cost of corn silage, we considered the yield of $34.7 \mathrm{t}$ of green matter/ha and a DM content of $39.05 \%$. Details about the items that comprise the costs of making silage can be found in Pacheco et al. (2006).

Calculations on labor costs considered one man/300 confined steers and three minimum wages/month/1,000 steers. In this calculation, two extra months were added for the preparation/maintenance of facilities and other activities.

Other operating expenses such as maintenance of infrastructure, machinery, implements and equipment, fuel, electricity, freight, taxes and feeding workforce were estimated as $2.5 \%$ of operating costs.

The equation of financial indicator Net Present Value (NPV, R\$/animal) used was:

$$
\sum_{i=1}^{n} \frac{\text { values }_{i}}{(1+\text { rate })^{i}}
$$

in which: values $=$ cash flow (revenue minus expenses in period "i"); $\mathrm{n}=$ number of periods considered; and rate = discount rate (\% per month).

To estimate the NPV, cash flows were developed within a planning horizon of one year, as suggested in Resende Filho et al. (2001), in which each slaughter weight, considering or disregarding the correlation amongst the input variables, was analised as a separate investment project.

Analyses of risk were performed using Microsoft Excel $^{\circledR}$ software, @ Risk ${ }^{\circledR}$ and SAS ${ }^{\circledR}$ system (Statistical Analysis System, version 9.4).

The cost items of each year were deflated by the IGP-FGV (Fundação Getúlio Vargas General Price Index - Anualpec, 2011) for the year 2010. Afterwards, the type of probability distribution of best fit (the AndersonDarling statistic - Palisade, 2010) of the following items was determined (Table 1): feeder steers $(\mathrm{R} \$ / \mathrm{kg})$, finished steers ( $\mathrm{R} \$ / \mathrm{kg}$ ), minimum wage ( $\mathrm{R} \$$ month), roughage $(\mathrm{R} \$ / \mathrm{kg} \mathrm{DM})$, concentrate $(\mathrm{R} \$ / \mathrm{kg} \mathrm{DM})$, facilities/equipment (R\$/animal/ day), machinery/implements (R $\$$ /animal/day), health/vaccine ( $\mathrm{R} \$ /$ dose), health/deworming $(\mathrm{R} \$ / \mathrm{mL})$, initial weight $(\mathrm{kg})$, final weight $(\mathrm{kg})$, average daily weight gain $(\mathrm{kg})$, total weight gain $(\mathrm{kg})$, roughage intake ( $\mathrm{kg} \mathrm{DM} /$ day), concentrate intake ( $\mathrm{kg} \mathrm{DM} /$ day) and minimum rate of attractiveness (\% per month). 
Table 1 - Descriptive estimates (distributions and parameters ${ }^{1}$ ) of input variables according to the slaughter weight

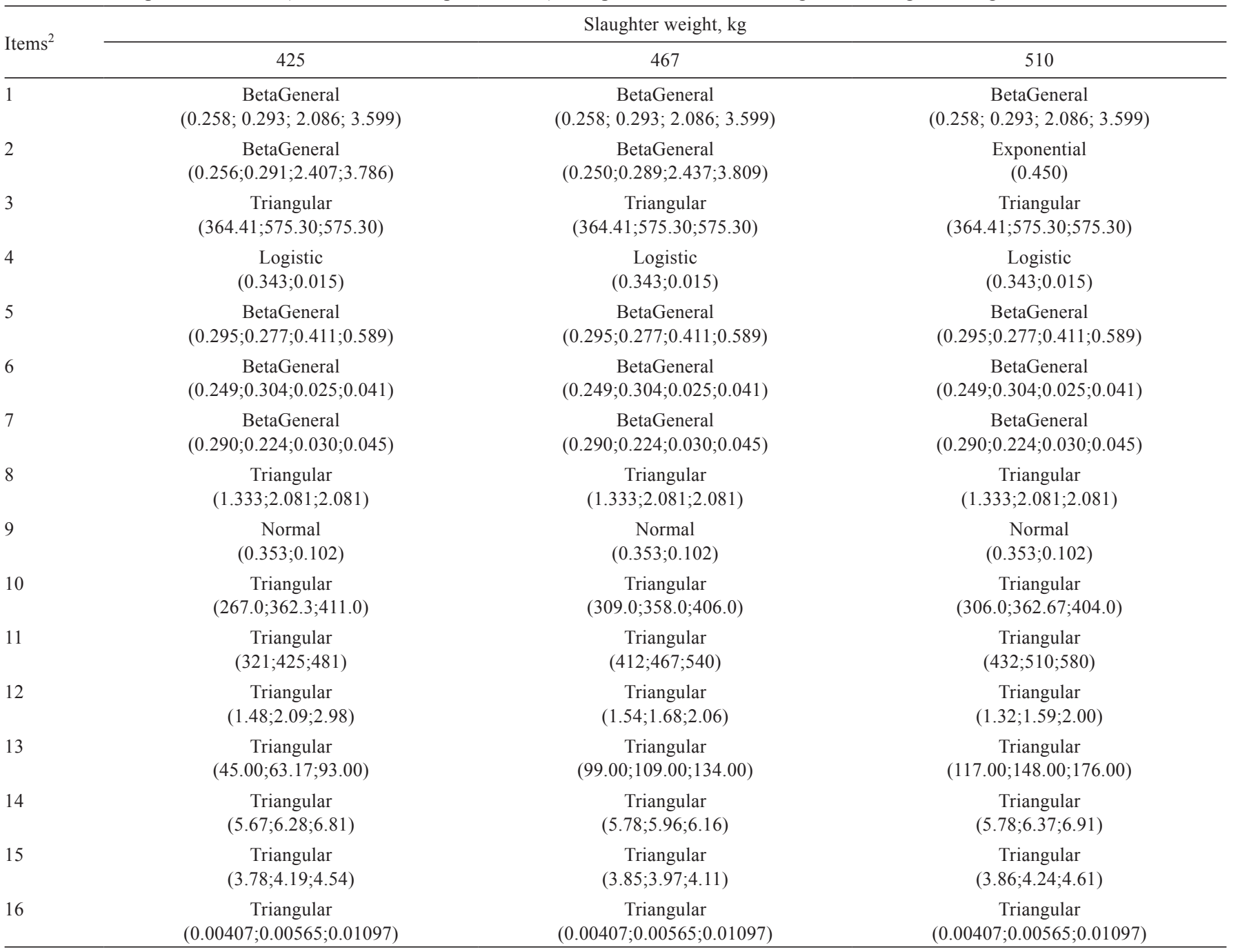

${ }^{1}$ BetaGeneral (alpha1; alpha2; minimum; maximum); Exponential (beta); Triangular (minimum; most probable; maximum); Logistic (alpha; beta); Normal (mean; standard deviation).

${ }^{2} 1$ Feeder steer $(\mathrm{R} \$ / \mathrm{kg}), 2$ Finished steer $(\mathrm{R} \$ / \mathrm{kg}), 3$ Minimum wage (R\$/month), 4 Roughage (R\$/kg DM), 5 Concentrate (R\$/kg DM), 6 Facilities/equipment (R\$/animal/day), 7 Machinery/implements (R \$/animal/day), 8 Health/vaccine (R $/$ dose), 9 Heath/deworming (R\$/mL), 10 Initial weight (kg), 11 Final weight (kg), 12 Average daily weight gain $(\mathrm{kg}), 13$ Total weight gain $(\mathrm{kg}), 14$ Roughage intake ( $\mathrm{kg} \mathrm{DM} /$ day), 15 Concentrate intake ( $\mathrm{kg} \mathrm{DM} /$ day), 16 Minimum rate of attractiveness (\% per month).

$1 \mathrm{R} \$=0.54 \mathrm{US} \$$.

In the simulation of NPV (output variable), Latin Hypercube type of sampling, with Mersenne Twister type of random number generator, was used to simulate 2,000 interactions (Palisade, 2010). The type of sampling and the random number generator used are recommended by Albright et al. (2010), for producing more accurate estimates of the distribution of the output variable and for being an algorithm with optimal statistical properties, respectively. For each slaughter weight, this analysis was performed with or without Spearman correlation between the cost items that had certain probability distribution (input variables) (Tables 2 and 3 ).

For the comparison of cumulative probability distributions of simulated NPV, the stochastic dominance of first and second order criterion was used (Hadar and
Russel, 1969; Anderson et al., 1977). In the criterion of stochastic dominance of first order, investments for investors who prefer higher returns are selected; in the stochastic dominance of second order, selected investments for investors who prefer high returns and low risk are selected. The Kolmogorov-Smirnov asymptotic test (Conover, 1999) was performed to check for differences (asymptotic value of $\mathrm{P}<0.05$ ) between pairs of cumulative distributions.

The risk analysis was complemented by a sensitivity analysis, using the Stepwise Multivariate regression method (Palisade, 2010) to identify and rank the cost items (input variables) with major influence on the NPV. This procedure generated standardized regression coefficients (Hamby, 1994), removing the influence of the units and placing all parameters at the same level. 
Table 2 - Spearman correlation coefficients of the items cost for the slaughter weight of $425 \mathrm{~kg}$ (below the diagonal) and $467 \mathrm{~kg}$ (above the diagonal)

\begin{tabular}{|c|c|c|c|c|c|c|c|c|c|}
\hline Items $^{1}$ & 1 & 2 & 3 & 4 & 5 & 6 & 7 & 8 & 9 \\
\hline 1 & & $0.99 * *$ & $0.67+$ & 0.54 & 0.43 & 0.05 & -0.11 & 0.27 & 0.36 \\
\hline 2 & $0.99 * *$ & & $0.67+$ & 0.62 & 0.47 & -0.03 & 0.01 & 0.33 & 0.34 \\
\hline 3 & $0.67+$ & $0.67+$ & & -0.01 & -0.27 & 0.48 & -0.43 & -0.15 & -0.24 \\
\hline 5 & 0.43 & 0.46 & -0.27 & $0.84 * *$ & & -0.60 & 0.65 & 0.52 & 0.63 \\
\hline 6 & 0.05 & -0.02 & 0.48 & $-0.76^{*}$ & -0.60 & & $-0.80^{*}$ & $-0.90 * *$ & $-0.73+$ \\
\hline 7 & -0.11 & -0.01 & -0.43 & $0.70+$ & $0.65+$ & $-0.80^{*}$ & & 0.63 & 0.27 \\
\hline
\end{tabular}

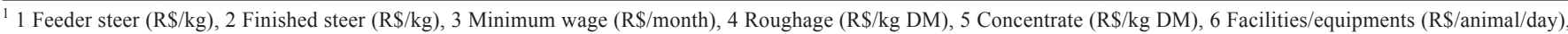
7 Machinery/implements (R\$/animal/day), 8 Health/vaccine (R $/$ dose), 9 Heath/deworming $(\mathrm{R} \$ / \mathrm{mL})$.

$* * \mathrm{P}<0.01 ; * \mathrm{P}<0.05 ;+\mathrm{P}<0.10$

Table 3 - Spearman correlation coefficients of items cost for the slaughter weight of $510 \mathrm{~kg}$

\begin{tabular}{lccccccc}
\hline Itens $^{1}$ & 1 & 2 & 3 & 4 & 5 & 6 & 7 \\
\hline 2 & $0.98^{* *}$ & & & & & & \\
3 & $0.68+$ & 0.63 & & & & & \\
4 & 0.54 & $0.66+$ & -0.01 & & & \\
5 & 0.42 & 0.46 & -0.27 & $0.84^{* *}$ & & \\
6 & 0.05 & -0.11 & 0.48 & $-0.76^{*}$ & -0.60 & & \\
7 & -0.12 & 0.05 & -0.43 & $0.70+$ & $0.65+$ & $-0.80^{*}$ & \\
8 & 0.27 & 0.44 & -0.15 & $0.81^{*}$ & 0.52 & $-0.90^{* *}$ & 0.63 \\
9 & 0.37 & 0.41 & -0.24 & $0.69+$ & 0.63 & $-0.73+$ & 0.27 \\
\hline
\end{tabular}

${ }^{1} 1$ Feeder steer (R\$/kg), 2 Finished steer (R\$/kg), 3 Minimum wage (R\$/month), 4 Roughage (R\$/kg DM), 5 Concentrate (R\$/kg DM), 6 Facilities/equipments (R\$/animal/day), 7 Machinery/implements (R\$/animal/day), 8 Health/vaccine (R\$/dose), 9 Heath/deworming (R\$/mL).

** $\mathrm{P}<0.01 ; * \mathrm{P}<0.05 ;+\mathrm{P}<0.10$.

\section{Results}

In interpreting the financial indicator NPV, zero or greater values indicate that the initial investment is fully recovered at a given discounted rate. Analyzing the NPV of slaughter weights considering the correlation amongst the input variables (Table 4), there is a negative mean, median and mode for $510 \mathrm{~kg}$, while for the weights of 425 and $467 \mathrm{~kg}$, mean, median, mode and SD were more favorable.

Furthermore, the difference was remarkable between $\mathrm{SD}$ and $\mathrm{CV}$ statistics in simulations considering or disregarding the correlation amongst input variables: more consistent results were usually observed when the correlation was considered. In the analysis using the correlation, the estimated probability for NPV $\geq 0$ was below $30 \%$ for $510 \mathrm{~kg}$, suggesting higher risk for this slaughter weight than for other weight options, which was also confirmed by a higher SD. Without the use of correlation in the simulation of $\mathrm{NPV}$, it is noticed that the probability of NPV $\geq 0$ decreased for slaughter weights of 425 and $467 \mathrm{~kg}$ and increased for $510 \mathrm{~kg}$.

Analyzing the curves with (Figure 1) and without correlation (Figure 2) and Kolmogorov-Smirnov asymptotic test (Table 5), it can be noticed that the slaughter weight of
$510 \mathrm{~kg}$ is dominated by others in the first order, because cumulative distribution curves for the weights of 425 and $467 \mathrm{~kg}$ do not intersect the curve of cumulative distribution for $510 \mathrm{~kg}$ in any time. However, for slaughter weights of 425 and $467 \mathrm{~kg}$, there was second order stochastic dominance, because there are times that intersections occur between the accumulated values.

Using the correlation to simulate NPV, it can be noted that in the analyzed slaughter weights, the seven most important items were, in order of importance, the price of finished steers, price of feeder steers, final weight, initial weight, concentrate cost, roughage cost, and minimum rate of attractiveness (Table 6).

Without the use of the correlation between input variables, the sensitivity analysis of the simulated NPV (Table 7) showed little difference in ranking of the items, but with significant changes in the regression coefficients, in which the estimated values were lower than the analysis with correlation.

It can also be noted that the variation in the cost of machinery/implements and facilities/equipments was more important when the correlation between the variables was not included in the simulation, whereas the variation in the cost of health was more important when the simulation included the correlation. 
Table 4 - Statistics of Net Present Value (NPV, R\$/animal) considering or disregarding the correlations amongst input variables, according to slaughter weight

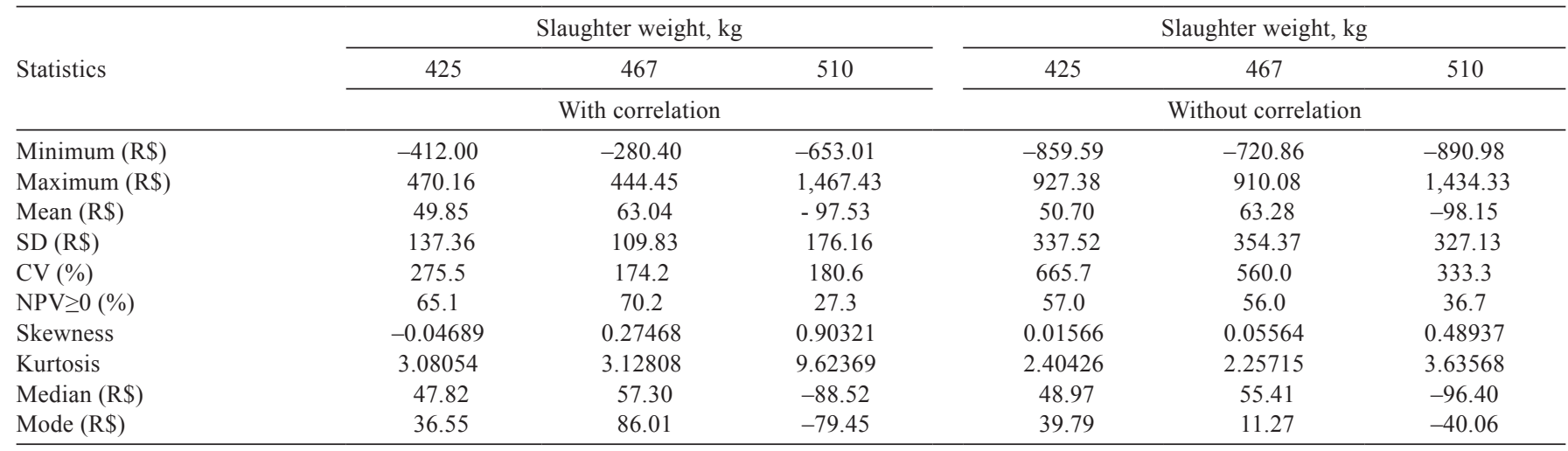

\section{$1 \mathrm{R} \$=0.54$ US\$}

$\mathrm{SD}$ - standard deviation.

$\mathrm{CV}$ - coefficient of variation.

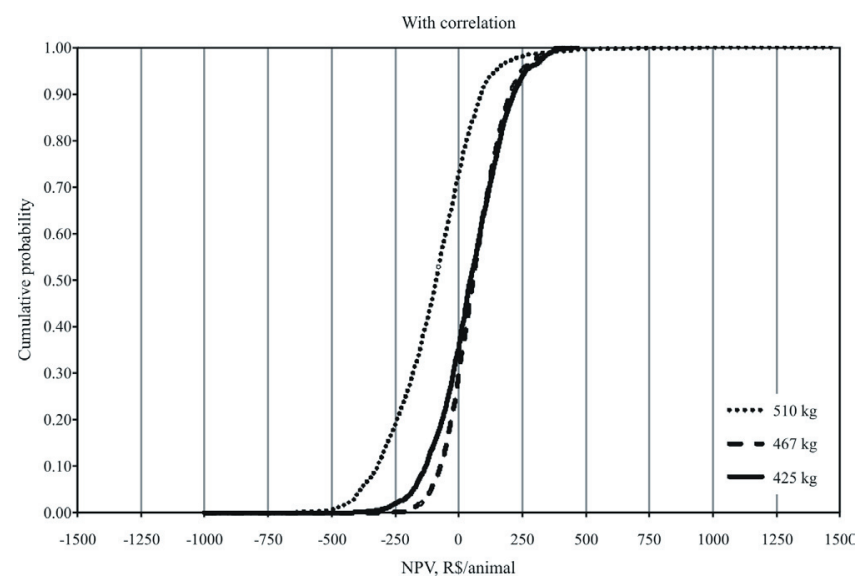

Figure 1 - Distribution of accumulated probability of the simulated Net Present Value (R \$/animal), with correlation amongst the input variables, according to slaughter weight ( $1 \mathrm{R} \$=0.54 \mathrm{US} \$$ ).

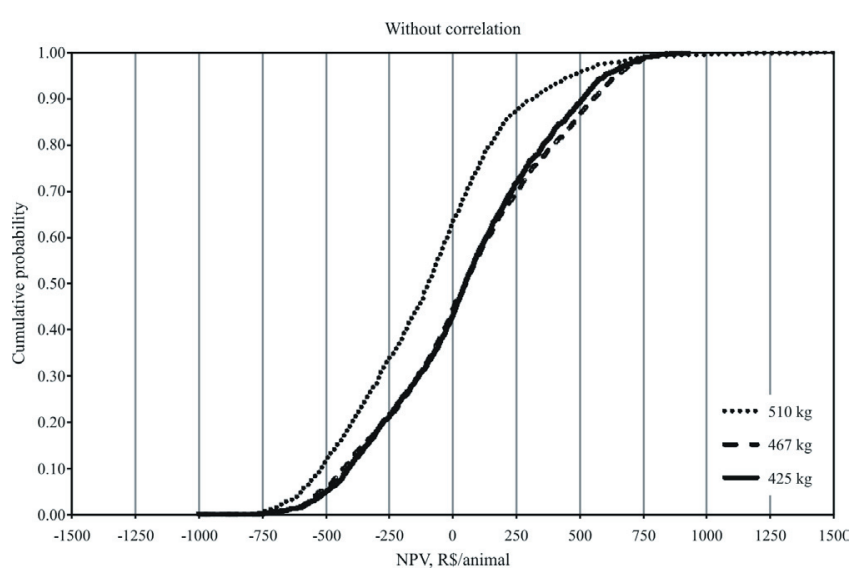

Figure 2 - Distribution of accumulated probability of the simulated Net Present Value (R \$/animal), without correlation amongst the input variables, according to slaughter weight ( $1 \mathrm{R} \$=0.54 \mathrm{US} \$$ ).

Table 5 - Stochastic dominance and probabilities of Kolmogorov-Smirnov asymptotic test of comparison of pairs of probability distributions of slaughter weight, considering or disregarding the correlation amongst the input variables for simulated Net Present Value

\begin{tabular}{|c|c|c|c|c|c|c|}
\hline \multirow{3}{*}{ Slaughter weight, $\mathrm{kg}$} & \multicolumn{3}{|c|}{ Slaughter weight, kg } & \multicolumn{3}{|c|}{ Slaughter weight, $\mathrm{kg}$} \\
\hline & 425 & 467 & 510 & 425 & 467 & 510 \\
\hline & \multicolumn{3}{|c|}{ With correlation } & \multicolumn{3}{|c|}{ Without correlation } \\
\hline 467 & $<$ & & $\mathrm{F}$ & $<$ & & $\mathrm{F}$ \\
\hline 510 & $>$ & $>$ & & $>$ & $>$ & \\
\hline
\end{tabular}

F - first-order stochastic dominance.

$\mathrm{S}$ - second-order stochastic dominance.

$>$ - treatment in the column dominates the treatment in the row.

$<-$ treatment in the column is dominated by the treatment in the row. 
Table 6 - Regression coefficients ${ }^{1}$ and rankings (in parentheses) of the most relevant variables to the simulated Net Present Value with a correlation amongst the input variables, according to slaughter weight

\begin{tabular}{|c|c|c|c|}
\hline \multirow{2}{*}{ Input variables } & \multicolumn{3}{|c|}{ Slaughter weight, $\mathrm{kg}$} \\
\hline & 425 & 467 & 510 \\
\hline Finished steers, $\mathrm{R} \$ / \mathrm{kg}$ & 1.668 (1) & 2.293 & $1.259(1)$ \\
\hline Feeder steers, $\mathrm{R} \$ / \mathrm{kg}$ & $-1.613(2)$ & -1.987 & $-1.244(2)$ \\
\hline Initial weight, $\mathrm{kg}$ & -0.625 & -0.514 (4) & -0.327 \\
\hline Roughage, R\$/kg DM & -0.071 & $-0.105 \quad(6)$ & -0.080 \\
\hline Concentrate, $\mathrm{R} \$ / \mathrm{kg} \mathrm{DM}$ & -0.058 (6) & -0.177 & -0.170 \\
\hline Health/deworming, R\$ & 0.030 & - & -0.010 \\
\hline Health/vaccine, R\$ & - & 0.019 & - \\
\hline Minimum wage, $\mathrm{R} \$ /$ month & - & $-0.025 \quad(8)$ & $-0.027(10)$ \\
\hline Discount rate, $\%$ per month & -0.039 & -0.080 & -0.060 \\
\hline Concentrate intake, $\mathrm{kg} \mathrm{DM} /$ day & $-0.008 \quad(10)$ & $-0.015 \quad(10)$ & $-0.039(9)$ \\
\hline Roughage intake, kg DM/day & -0.011 & -0.014 & $-0.046(8)$ \\
\hline
\end{tabular}

${ }^{1}$ Standard multivariate regression coefficient indicating the number of standard deviations of NPV that will change with each alteration of a standard deviation in the input variables (assuming all other input variables are constant).

$1 \mathrm{R} \$=0.54$ US\$.

$\mathrm{R}^{2}$ - coefficient of determination.

Table 7 - Regression coefficients ${ }^{1}$ and rankings (in parentheses) of the most relevant variables to the simulated Net Present Value without correlation between the input variables, according to slaughter weight

\begin{tabular}{|c|c|c|c|}
\hline \multirow{2}{*}{ Input variables } & \multicolumn{3}{|c|}{ Slaughter weight, $\mathrm{kg}$} \\
\hline & 425 & 467 & 510 \\
\hline Finished steers, $\mathrm{R} \$ / \mathrm{kg}$ & 0.658 (1) & 0.716 (1) & 0.675 (1) \\
\hline Feeder steers, $\mathrm{R} \$ / \mathrm{kg}$ & $-0.633(2)$ & $-0.623(2)$ & $-0.675(2)$ \\
\hline Final weight, $\mathrm{kg}$ & 0.295 & 0.221 & $0.256(3)$ \\
\hline Initial weight, $\mathrm{kg}$ & -0.253 & -0.161 & -0.175 (4) \\
\hline Roughage, R\$/kg DM & $-0.016(6)$ & -0.029 (6) & $-0.045(6)$ \\
\hline Concentrate, $\mathrm{R} \$ / \mathrm{kg} \mathrm{DM}$ & -0.028 & $-0.054(5)$ & $-0.087(5)$ \\
\hline Machinery/implements, R\$/animal/day & $-0.005 \quad(11)$ & $-0.006(10)$ & $-0.006(12)$ \\
\hline Facilities/equipments, R\$/animal/day & $-0.005 \quad(12)$ & -0.007 (8) & $-0.008(10)$ \\
\hline Health/deworming, R\$ & - & - & - \\
\hline Health/vaccine, R\$ & - & - & - \\
\hline Minimum wage, $\mathrm{R} \$ /$ month & -0.007 (9) & $-0.006(9)$ & $-0.008(11)$ \\
\hline Discount rate, $\%$ per month & -0.014 & -0.023 & $-0.032(7)$ \\
\hline Concentrate intake, $\mathrm{kg} \mathrm{DM} /$ day & $-0.006 \quad(10)$ & -0.005 (11) & $-0.023(8)$ \\
\hline Roughage intake, $\mathrm{kg} \mathrm{DM}$ /day & -0.009 & $-0.005 \quad(12)$ & $-0.023(9)$ \\
\hline $\mathrm{R}^{2}$ & 0.994 & 0.997 & 0.997 \\
\hline
\end{tabular}

${ }^{1}$ Standard multivariate regression coefficient indicating the number of standard deviations of NPV that will change with each alteration of a standard deviation in the input variables (assuming all other input variables are constant).

$1 \mathrm{R} \$=0.54 \mathrm{US} \$$.

$\mathrm{R}^{2}$ - coefficient of determination.

\section{Discussion}

The interpretation of the statistics of the simulated NPV (Table 3) is of great value in decision making; regardless of whether or not the correlation is used, feeding animals to reach $510 \mathrm{~kg}$ proved to be the worst investment option among the three slaughter weights evaluated.

Although no studies evaluating the risk of feedlotfinishing cattle with different weights were found, there is evidence that fattening may involve higher risks than other stages of the production system. Simões et al. (2007) economically evaluated cattle production systems (breeding, rearing and fattening) and found that the fattening system had the highest amplitude of mean $(\mathrm{CV}=206.41 \%)$, followed by rearing $(\mathrm{CV}=135.38 \%)$ and breeding $(\mathrm{CV}=19.47 \%)$, suggesting these stages of production had high, medium and low risks, respectively.

Among slaughter weights, considering or disregarding the input variables correlation, the skewness and kurtosis were not adequate indicators for decision making, in which the slaughter weight of $510 \mathrm{~kg}$, for example, would be the best investment option indicating a tail closer to the right 
side of the mean (skewness) and more acute curve shape (kurtosis). This fact does not correspond to the negative value of the mean of NPV for this slaughter weight.

Considering the average of the three slaughter weights, there was an increase in standard deviations when the input variables correlation was not accounted for in the NPV simulation, representing a difference of $141 \%$. Thus, the advantage of using the correlation between input variables aiming to simulate the variable output is evident, obtaining more accurate estimate of the degree of risk associated with the investment.

Mun (2006) and Albright et al. (2010) simulated the revenue using positive, zero or negative correlation, noting that the mean remained relatively stable, indicating that correlations do not affect much the expected value of projects, but can reduce or increase the risk thereof. Further studies in other areas of research have estimated the impact on simulated results with or without the correlation. Wall (1997) evaluated the use of the Monte Carlo simulation analysis of costs in the construction sector comparing different types of distribution of random input variables with and without correlation between them and concluded that the effect of excluding the correlations was more striking than the choice between beta or lognormal distribution. In another study, Yang (2005) used a the Monte Carlo simulation to provide a general method for incorporating correlations between cost items in the cost estimation process and found that the impact of the correlations was significant, and when neglected, caused serious problems such as increase in SD and underestimation of the unit cost of the project.

In simulation analysis, one of the benefits of using the probability distribution is to facilitate the interpretation of risk, allowing decision makers to choose more safely whether or not to invest in projects. For example, the results (Table 4) of the estimated probability for NPV $\geq 0$ to $510 \mathrm{~kg}$ are very relevant to the feedlots in Brazil, where the average slaughter weight of castrated and non-castrated males is 489 and $501 \mathrm{~kg}$, respectively (Millen et al., 2009). This indicates the need for careful evaluations in order to define the best slaughter weight of animals confined in Brazilian conditions. Analyzing three systems of livestock production (breeding, rearing and fattening) for the Pantanal region of Mato Grosso do Sul, Simões et al. (2007) found that the fattening system had a higher risk (28\% probability of negative profit). The authors argued that the increased risk in finishing systems is due to the behavior of the fixed and variable costs. While in the breeding system $44.87 \%$ of the total costs were variable, in the fattening system, $90.47 \%$ were variable, making the latter system highly dependent on fluctuations in market prices. Further studies evaluating feedlot finishing have also demonstrated the low relevance of fixed costs, and showed that two items of variable costs were the most representative in relation to the total cost: purchase price of feeder animals and feeding costs (Pacheco et al., 2006; Ferreira et al., 2009; Lopes et al., 2011). Increases in feeding time in feedlots (Restle et al., 2007) or in the level of concentrate (Missio, 2007) may change this order.

The curves (Figure 1 and 2) showed that the differences between cumulative probability distribution for the weights of 425 and $467 \mathrm{~kg}$ were not so clear. In this case, the Kolmogorov-Smirnov asymptotic test represents a very efficient statistical feature for validating the difference between pairs of curves, in which the slaughter weight of $467 \mathrm{~kg}$ dominated the $425 \mathrm{~kg}$ when input variables correlations where considered or disregarded. This decision is also supported by the observation of the superiority of the mean and the minimum value of $467 \mathrm{~kg}$ weight in relation to the $425 \mathrm{~kg}$ (Table 3). Therefore, the slaughter weight of $467 \mathrm{~kg}$ presented the highest return and the lowest risk among all evaluated slaughter weights. Assessing the risk of beef cattle feedlot, Resende Filho et al. (2001) used the stochastic dominance criterion for decision-making regarding three feedlot systems, and found that a cattle breeder less averse to risk might prefer the feedlot strategy with two fattening periods per year (beginning in July and October), because it presents a larger maximum gain than the strategy with only one fattening per year (beginning in July).

The sensitivity analysis showed the importance, now economically quantified, of commercialization, purchase of supplies and manufacturing the diet, and more biologically efficient genotypes. Several studies involving the deterministic economic evaluation of feedlot cattle in different regions of Brazil (Restle et al., 2007; Lopes et al., 2011) agree with this comment, although with no sensitivity analysis. Analyzing economic aspects related to finishing cattle of different genetic groups in feedlots, Ferreira et al. (2005) evaluated the sensitivity of gross margin and found that it was more sensitive to variations in the purchase price of thin animals, followed by the sale price of beef, soybean and finally, corn (diet-related).

Considering feedlot-finishing a technology of high investment, Lopes et al. (2011) commented on the importance of knowing the market and the need for pricing, recommending future contracts at BM \& F (Brazilian Mercantile \& Futures) and cattle term contracts with the meatpacking industry as the main options, because they allow for fixing the selling price beforehand. This kind of marketing may, for example, avoid speculation as to the 
purchase/sale of animals, reducing uncertainty of pricing in the physical market as well as price fluctuations.

However, many producers in Brazil are not yet familiar with this type of marketing, preferring alternatives such as participation in bonus programs from the meatpacking industry and/or large retailers as well as adjustment the production system focusing on quality attributes of the final product (age, carcass weight and subcutaneous fat thickness) to meet market niches.

From the methodological point of view, incorporation of the correlation amongst input variables improves the quality/robustness of financial risk measurement as it allows for the incorporation of dependent relations in the analysis. In practice, the sensitivity analysis presented in this study demonstrates the importance of technical efficiency in the management of feedlots as an alternative for finishing beef cattle, having a direct impact on the economic response. The efficiency and marketing in production of diets are priority issues in the implementation of feedlot system as well as not-so-high slaughter weights, which do not result in prolonged feeding time. Moreover, small changes in beef price, feeder cattle purchase price and cost of the diet (roughage and concentrate) may define the economic viability of this finishing system, regardless of animal slaughter weight.

\section{Conclusions}

The use of input variables correlation improves the estimates of the output variable, Net Present Value, producing more consistent results than simulations that disregard such relationship amongst variables. According to risk analysis, the $467 \mathrm{~kg}$ slaughter weight presents the lowest risk for finishing cattle in feedlots when compared with 425 and $510 \mathrm{~kg}$. The most important variables influencing the Net Present Value are the prices of feeder and finished steers, initial and final weights, concentrate and roughage costs, and minimum rate of attractiveness, demonstrating the importance that should be given to these variables when deciding on feedlot finishing, to obtain economic success.

\section{References}

Albright, S. C.; Winston, W. L. and Zappe, C. J. 2010. Data analysis and decision making. 4th ed. South-Western College Pub, Ohio.

Anderson, J. R.; Dillon, J. L. and Hardaker, B. 1977. Agricultural decision analysis. Iowa State University Press, Iowa.
ANUALPEC - Anuário da pecuária brasileira. 2011. Informa Economics FNP, São Paulo.

CONAB - Companhia Nacional de Abastecimento. 2010. Custos de produção agrícola: a metodologia da Conab. Conab, Brasília.

Conover, W. J. 1999. Practical nonparametric statistics. 3rd ed. Wiley, New York.

Ferreira, I. C.; Silva, M. A.; Reis, R. P.; Euclides Filho, K.; Figueiredo, G. R.; Fridrich, A. B.; Corrêa, G. S. S.; Valente, B. D. and Felipe-Silva, A. S. 2005. Análise de sensibilidade da margem bruta da receita e dos custos do confinamento de diferentes grupos genéticos. Arquivo Brasileiro de Medicina Veterinária e Zootecnia 57:93-103.

Ferreira, I. C.; Silva, M. A.; Barbosa, F. A.; Carvalho, A. D. F.; Correa, G. S. S.; Fridrich, A. B. and Souza, J. E. R. 2009. Avaliação técnica e econômica de diferentes grupos genéticos de bovinos de corte machos superprecoces e do sistema de produção em confinamento. Arquivo Brasileiro de Medicina Veterinária e Zootecnia 61:243-250.

Hadar, J. and Russell, W. R. 1969. Rules for ordering uncertain prospects. American Economic Review 59:25-34.

Hamby, D. M. 1994. A review of techniques for parameter sensitivity analysis of environmental models. Environmental Monitoring and Assessment 32:135-154.

Lopes, L. S.; Ladeira, M. M.; Machado Neto, O. R.; Silveira, A. R. M. C.; Reis, R. P. and Campos, F. R. 2011. Viabilidade econômica da terminação de novilhos Nelore e Red Norte em confinamento na região de Lavras-MG. Ciência e Agrotecnologia 35:774-778.

Matsunaga, M.; Bemelmans, P. F.; Toledo, P. E. N.; Dulley, R.D.; Okawa, H. and Pedroso, I. A. 1976. Metodologia de custo utilizada pelo IEA. Agricultura em São Paulo 23:123-139.

Millen, D. D.; Pacheco, R. D. L.; Arrigoni, M. D. B.; Galyean, M. L. and Vasconcelos, J. T. 2009. A snapshot of management practices and nutritional recommendations used by feedlot nutritionists in Brazil. Journal of Animal Science 87:3427-3439.

Missio, R. L. 2007. Níveis de concentrado na dieta de bovinos. Dissertação (M.Sc.). Universidade Federal de Santa Maria, Santa Maria.

Mun, J. 2006. Modeling risk: Applying Monte Carlo simulation, real options analysis, forecasting, and optimization techniques. John Wiley \& Sons, Inc., New Jersey.

NRC - National Research Council. 1996. Nutrient requirements of beef cattle. 7th rev. ed. National Academy Press, Washington, DC.

Pacheco, P. S.; Restle, J.; Vaz, F. N.; Freitas, A. K.; Padua, J. T.; Neumann, M. and Arboitte, M. Z. 2006. Avaliação econômica da terminação em confinamentode novilhos jovens e superjovens de diferentes grupos genéticos. Revista Brasileira de Zootecnia 35:309-320.

PALISADE - 2010. @RISK: Risk analysis and simulation add-in for Microsoft ${ }^{\circledR}$ Excel. Palisade Corporation, New York.

Resende Filho, M. A.; Braga, M. J. and Rodrigues, R. V. 2001. Sistemas de terminação em confinamento: perspectivas para dinamização da cadeia produtiva da carne bovina em Minas Gerais. Revista Brasileira de Economia 55:107-131.

Restle, J.; Pacheco, P. S.; Costa, E. C.; Freitas, A. K.; Vaz, F. N.; Brondani, I. L. and Fernandes, J. J. R. 2007. Apreciação econômica da terminação em confinamento de novilhos Red Angus superjovens abatidos com diferentes pesos. Revista Brasileira de Zootecnia 36:978-986.

Simões, A. R. P.; Moura, A. D. and Rocha, D. T. 2007. Avaliação econômica comparativa de sistemas de produção de gado de corte sob condições de risco no Mato Grosso do Sul. Revista de Economia e Agronegócio 5:51-72.

Wall, D. M. 1997. Distributions and correlations in Monte-Carlo simulation. Construction Management and Economics 15:241-258.

Yang, I.-T. 2005. Simulation-based estimation for correlated cost elements. International Journal of Project Management 23:275-282. 